Nursing News: Jurnal Ilmiah Keperawatan Vol 5, No Tahun 2021, hal 24-30

Tersedia online di https://publikasi.unitri.ac.id/index.php/fikes

ISSN 2527-9823(online

\title{
Peningkatan Kebutuhan Tidur Lansia Melalui Penerapan Relaksasi Otot Progresif Di Panti Sosial Budi Mulya 1 Cipayung Jakarta Timur
}

\author{
Sri Nyumirah ${ }^{1}$ \\ Akademi Keperawatan Pasar Rebo \\ e-mail : srinyumirah@yahoo.co.id
}

\begin{abstract}
Changes in sleep patterns become a phenomenon that is felt by the elderly at the stage of development, this is in accordance with the results of a survey that the elderly who experience changes in sleep patterns are almost $50 \%$ at the age above 65 years who live at home. In the aging process that affects the occurrence of changes in sleep patterns due to environmental factors, biological factors and psychosocial factors. Many studies have been conducted on the relationship between sleep and wakefulness mechanisms with aging, although sleep and wakefulness have a very different spectrum of behaviors, both of which are believed to have been regulated by a small number of general physiological functions and neurochemical mechanisms (Maas et al., 2014). Progressive muscle relaxation techniques are techniques that focus muscle activity by relaxing it, not imagination, persistence, or suggestion and give confidence that the human body will respond to something that causes anxiety and events that stimulate the mind (Herod, 2010). The aim of the study was to determine the changes in sleep needs of the elderly after progressive muscle relaxation techniques were carried out in social institutions. Research design pre-post test in one group (one group pre-post test design). A sample of 28 elderly who live in social institutions by taking samples with accidental sampling. The results showed that there was an increase in the need for sleep in the elderly after applying progressive relaxation techniques ( $p$ value $<0.05$ ).
\end{abstract}

Keywords : Sleep; Relaxation; Progressive

\begin{abstract}
ABSTRAK
Perubahan pola tidur menjadi suatu fenomena yang dirasakan oleh lansia pada tahap perkembangannya, hal ini sesuai dengan hasil survai bahwa lansia yang mengalami perubahan pola tidur hampir 50\% pada usia diatas 65 Tahun yang tinggal di rumah. Pada proses penuaan yang mempengaruhi terjadinya perubahan pola tidur karena faktor lingkungan, faktor biologis dan faktor psikososial. Banyak penelitian yang telah dilakukan bahwa hubungan mekanisme tidur dan terjaga dengan penuaan, walaupun tidur dan terjaga memiliki spektrum perilaku yang sangat berbeda, keduanya diyakini telah diatur oleh sebagian kecil fungsi fisiologis umum dan mekanisme neurokimiawi (Maas dkk, 2014). teknik relaksasi otot progresif yaitu tehnik yang dilakukan dengan memusatkan aktivitas otot dengan merilekskannya bukan imajinasi, ketekunan, atau sugesti dan memberikan keyakinan bahwa tubuh manusia akan berespons pada suatu hal yang
\end{abstract}

Cara mengutip: Nyumira, S.( 2021). Peningkatan Kebutuhan Tidur Lansia Melalui Penerapan Relaksasi Otot Progresif Di Panti Sosial Budi Mulya 1 Cipayung Jakarta Timur. Nursing News: Jurnal Ilmiah Keperawatan. Vol 5, No 21, 2021, hal 24-30. Retrieved from https://publikasi.unitri.ac.id/index.php/fikes/article/view/2273 
menyebabkan kecemasan dan kejadian yang merangsang pikiran tersebut (Herodes, 2010). Tujuan penelitian untuk mengetahui perubahan kebutuhan tidur lansia setelah dilakukan teknik relaksasi otot progresif di panti sosial. Desain penelitian pra-post test dalam satu kelompok (one group pre-post test design). Sampel berjumlah 28 lansia yang tinggal di panti sosial dengan cara mengambil sampel dengan accidental sampling. Hasil penelitian menunjukkan ada peningkatan kebutuhan tidur lansia setelah di terapkan tehnik relaksasi progresif dengan ( $\mathrm{p}$ value $<0,05$ ).

Kata kunci: Tidur; Relaksasi; Progresif

\section{PENDAHULUAN}

Tahap perkembangan diusia lansia terutama usia 65 Tahun ke atas yaitu terganggunya kebutuhan tidur terutama lansia yang tinggal di panti sosial. Kebutuhan tidur merupakan kebutuhan dasar fisiologis yang setiap orang membutuhkannya yang harus bermanfaat secara maksimal, dalam kondisi sehat maupun kurang sehat. Tidur sangat berguna untuk kesehatan fisik dan psikologis supaya tidak terjadi kondisi lelah dan capek, jika ada yang terganggu kebutuhan tidur maka waktu sehatnya akan lebih lama dibanding saat kondisi sehat, dengan istirahat yang cukup, maka akan dapat bekerja secara optimal (Potter \& Perry, 2011). Setiap manusia memiliki kebutuhan tidur yang berbeda-beda dengan tepat dan secara konsisten. Pola tidur yang baik dan teratur memberikan dampak yang baik untuk kesehatan tubuh (Tarwoto dan Wartonah, 2010).

Berdasarkan hasil penelitian (Chasanah
N, 2017) tentang korelasi kualitas tidur dengan kualitas hidup pada lansia bahwa ada hubungan yang signifikan pola tidur dengan kualitas hidup pada lansia, dimana semakin baik pola tidur maka kualitas hidup lansia pun semakin baik. Berdasarkan hasil penelitian (Lubis Marliyana, 2011) tentang kebutuhan istirahat tidur pada lansia yang harus dipenuhi di Panti sosial menunjukkan hasil bahwa kebutuhan tidur lansia terpenuhi cukup (70\%), kebutuhan tidur yang baik (25\%), kebutuhan tidur yang kurang (5\%), menyimpulkan hasil tersebut bahwa lansia yang di panti sosial mayoritas pola tidurnya cukup.

Menurut (Kozier, 2014) Akibat yang terjadi pada lansia, ketika kebutuhan tidurnya tidak terpenuhi secara optimal, contoh: tidur berlebihan saat siang hari. Penurunan daya ingat, gangguan depresi, resiko jatuh, penggunaan hipnotik yang mempengaruhi menurunnya kualias hidup. Akibat lain yang dapat terjadi 
ketika kualitas tidur tidak tercapai akan mudah lelah, letih, mudah emosi dan gangguan mood. Menurut (Potter\&Perry, 2011) menyampaikan bahwa kebutuhan tidur akan terpenuhi saat keadaan relaks otot dan pikiran lebih tenang. Perawat harus memahami tentang gerakan otot yang relaks karena kecemasan yang mempengaruhi kebutuhan tidur. Tindakan keperawatan yang dapat dilakukan untuk lansia dalam mencukupi kebutuhan tidur yaitu atur pola tidur, lingkugan yang tenang, proses meditasi, mengatur pola makan, olahraga dan memantau kondisi kesehatan. Tindakan keperawatan yang dapat dilakukan pada klien untuk mengatasi masalah pola tidur dengan relaksasi otot, memijat punggung dan latihan guided imageri.

Berdasarkan hasil penelitian (Rahmadona F, 2012) tentang penerapan relaksasi otot progresif dengan pemenuhan kebutuhan tidur lansia bahwa ada pengaruh yang signifikan dalam meningkatkan pemenuhan kebutuhan tidur lansia. Berdasarkan hasil penelitian (Widad L, 2013) tentang penerapan teknik relaksasi progresif pada pemenuhan kebutuhan tidur pada lansia bahwa ada perubahan yang signifikan relaksasi progresif terhadap pemenuhan kebutuhan tidur pada lansia . Berdasarkan hasil penelitian
(Prasetya, 2016) tentang penurunan tingkat insomnia lansia setelah dilakukan tehnik relaksasi otot progresif karena salah satu terapi ini sanga efektif figunakan untuk mengurangi otot yang tegang dan kaku sehingga otot dan badan menjadi rileks dan kembali segar.

Berdasarkan hasil studi pendahuluan yang dilakukan, bahwa lansia yang berada di Panti sosial dari enam ruangan dengan jumlah lansia 206, lansia yang mengalami gangguan pola tidur sebanyak 53 lansia (25\%) dari jumlah lansia yang di wawancarai. Sebagian lansia yang mengalami gangguan pola tidur yaitu di sebabkan masalah gangguan istirahat tidur dikarenakan ganguuan eliminasi urine sebanyak 10\%, kondisi lingkungan sebanyak $10 \%$, dan sebanyak 5\% karena ada kondisi psikologis yang sedang dipikirkan sehingga sulit untuk memulai tidur atau tidurnya sering terbangun.

Fenomena diatas memberi gambaran kepada peneliti bahwa lansia yang tinggal di panti sosial mengalami gangguan tidur karena gangguan fisik dan gangguan psikologis, Pola tidur sangat dipengaruhi dari keyakinan lansia dan kemampuan lansia dalam merilekskan tibuh dan kondisi psikologis, maka 
perlu salah satu alternatif tindakan yaitu dengan melakukan tehnik relaksasi otot progresif.

\section{METODE PENELITIAN}

Rancangan penelitian menggunakan prapost test dalam satu kelompok (one group pre-post test design). Jenis penelitian yang digunakan dalam penelitian ini adalah penelitian pre-eksperimental dengan pendekatan observasional. Populasi yang diambil dalam penelitian ini adalah lansia di Panti Werdha Budi Mulya 1 Cipayung Jakarta Timur sebanyak 200 orang. Penentuan besarnya sampel dari populasi yang ada maka digunakan rumus Slovin dengan tehnik accidental sampling dan tetap mempertimbangkan karakteristik yang ada, dengan hasil 190 sampel. Intrumen penelitian menggunakan pedoman teknik relaksasi otot progresif berdasarkan modul panduan pelaksanaan relaksasi otot progresif dan Cheklist; data objektif tentang kebutuhan istirahat tidur (10 item). Menggunakan skala likert, kedua data tersebut dijumlahkan didapatkan rentang nilai $0-80$. Nilai maksimal 80 , minimal 0.Hasil ukur: Kebutuhan istirahat tidur tidak terpenuhi: 41-80, Terpenuhi: 0-40.

\section{HASIL PENELITIAN}

Tabel 1. Distribusi Responden Berdasarkan Jenis Kelamin, Agama dan Pendidikan di Panti Werdha Budi Mulya 1 Cipayung Jakarta Timur Tahun 2019 ( $\mathrm{N}=28)$

\begin{tabular}{|c|c|c|c|}
\hline Variabel & & Frekuensi & $(\%)$ \\
\hline Jenis & Perempua & 24 & 85.7 \\
\hline \multirow[t]{2}{*}{ Kelamin } & $\begin{array}{l}\mathrm{n} \\
\text { Laki-Laki }\end{array}$ & 4 & 14.3 \\
\hline & Total & 28 & 100 \\
\hline \multirow{5}{*}{$\begin{array}{l}\text { Pendidik } \\
\text { an }\end{array}$} & SD & 17 & 60.7 \\
\hline & SMP & 5 & 17.9 \\
\hline & SMA & 5 & 17.9 \\
\hline & Kuliah & 1 & 3.6 \\
\hline & Total & 28 & 100 \\
\hline \multirow[t]{4}{*}{ Agama } & Islam & 24 & 85.7 \\
\hline & Kristen & 3 & 10.7 \\
\hline & Katolik & 1 & 3.6 \\
\hline & Total & 28 & 100 \\
\hline
\end{tabular}

Tabel 2. Distribusi Rata-Rata Skor Pemenuhan Kebutuhan Tidur Setelah dilakukan Tehnik Relaksasi Progresif di Panti Werdh Mulya 1 Cipayung Jakarta Timur Tahun 2019 ( $\mathrm{N}=28)$

\begin{tabular}{|l|c|c|c|c|c|}
\hline $\begin{array}{l}\text { Variabel } \\
\text { Kebutuhan } \\
\text { tidur }\end{array}$ & Mean & SD & SE & $\begin{array}{c}p^{-} \\
\text {valu }\end{array}$ & $\mathbf{N}$ \\
\hline $\begin{array}{l}\text { Sebelum } \\
\text { Intervensi }\end{array}$ & 51.00 & 6.79 & 1.29 & 0.00 & 28 \\
Setelah & 20.61 & 6.29 & 1.19 & $0^{*}$ & \\
Intervensi & & & & & \\
\hline
\end{tabular}

Berdasarkan tabel diatas disimpulkan bahwa uji statistik yang dihasilkan dengan nilai $\mathrm{p} 0.000$, terdapat pengaruh 
kebutuhan idur lansia dengan pemberian terapi relaksasi otot progresif

\section{PEMBAHASAN}

Dari hasil uji statistik bahwa ada peningkatan kebutuhan tidur pada lansia setelah diberikan terapi relaksasi otot progresif di panti sosial dengan nilai $\mathrm{p}$ 0.000. Lansia mempunyai gangguan tidur diberikan relaksasi otot progresif mampu merilekskan otot sehingga memberikan kenyamanan pada lansia dampaknya lansia menjadi lebih rileks dan otot menjadi tidak kaku, sehingga kebutuhan tidur lansia terpenuhi (Hart, 2013).

Berdasarkan hasil penelitian Hidayat (2019) mengatakan bahwa ada perbedaan kualitas tidur yang signifikan pada lansia sebelum dilakukan tehnik relaksasi otot dan sesudah dilakukan tehnik relaksasi otot, hal ini juga didukung oleh penelitian Sumiarsih dan Widad (2013) bahwa kualitas tidur lansia berkualitas dan terpenuhi setelah diterapkan relaksasi otot progresif, sehingga kebutuhan tidur lansia meningkat.

Penelitian lain yang dilakukan oleh Johnson cit Maas et al (2011) bahwa terapi relaksasi otot progresif yang diterapkan pada lansia akan meningkatkan jam tidur lansia, sehingga menurun jumlah terbangun tidur ditengah malam, tidur lebih tenang dan rileks, saat bangun tidur lebih ceria dan segar, melakukan aktivitas menjadi semangat. Lansia lebih banyak mengatakan tidurnya hanya sebentar tidak sampai 5 jam. Lansia yang menerapkan relaksasi otot progresif menyampaikan bahwa lebih lama dan panjang tidurnya, bangun tidurbadan menjadi rileks dan semangat, sehingga relaksasi otot progresif sangant efektif untuk meningkatkan pola tidur lansia.

Salah satu tehnik yang efektif pada setiap manusia tergantung masingmasing individu dalam menggunakan kemampuannya untuk merilekskan otot dalam tubuh individu. Tubuh bekerja secara optimal sehingga mengakibatkan stres terlalu berlebihan dan mengganggu kebutuhan tidur, maka perlu dilakukan penerapan teknik relaksasi otot progresif mengurangi gejala fisik yang muncu, sehingga ketika ada respon stres pada sistem saraf dan hormon yang meningkat dan dapat membuat lansia lebih tenang dan membuat tenang secara fisik dan psikologis yang akan mempengaruhi fisik dan pikiran lansia selain itu bisa membantu tidur seseorang yang lebih optimal dan berkualitas. Relaksasi berupa dari 
imajinasi psikologis, pelatihan otogenik, terapi musik, olahraga latihan tarik nafas dalam, relaksasi progresif, serta meditasi (Davis, 2017).

Penerapan tehnik relaksasi otot progresif mampu mengubah lansia yang mengalami masalah pada pola tidur sehingga kondisi fisiologis yang tegang menjadi rileks, relaksasi otot dalam tubuh meningkat, cemas berkurang, sehingga terjadi pelebaran pembuluh darah, aliran darah sistemik menjadi lancar, denyut nadi berdetak normal, jumlah nafas normal dan eraporasi berkurang, sehingga pikiran menjadi fokus, rileks dan terasa nyaman. Dampak yang terjadi menurunnya aktivitas RAS (Reticullar Activating System) dari aktivitas meningkatkan batang otak, hal ini dapat membantu menyelesaikan masalah cemas, insomnia, kelelahan, kram otot dan meningkatkan aktivitas (Davis, 2017).

\section{KESIMPULAN}

Dari penelitian menujukkan bahwa lansia yang mempunyai masalah pola tidur sebagian besar perempuan dengan tingkat pendidikan sebagian besar SD dan mayoritas beragama Islam. Rata-rata usia mayoritas diatas 65 Tahun. Ada peningkatan kebutuhan tidur lansia setelah dilakukan tehnik relaksasi otot progresif, sehingga ada pengaruh intervensi yang telah dilakukan.

\section{SARAN}

Penelitian ini dapat direkomendasikan menjadi referensi dan diperlukan untuk selanjutnya tidak hanya melakukan penelitian secara kuantitas tapi lebih kepada penelitian yang bersifat kualitatif terutama yang berkaitan dengan pemenuhan kebutuhan istirahat tidur dan faktor-faktor yang berpengaruh seperti lingkungan, penyakit yang dialami dan faktor psikologi/kecemasan saat berada di Panti Werdha .

\section{UCAPAN TERIMAKASIH}

Penulis memberikan ucapan terima kasih yang setulusnya kepada :

1. Ns. IGA Dewi P, M.Kep.,Sp.Kep.An, sebagai Direktur Akper Pasar Rebo

2. Lucia F, M.Kes, sebagai Ketua LPPM

3. Kepala Dinas Sosial Jakarta timur

4. Kepala Panti Sosial Budi Mulya 1 Cipayung dan Budi Mulya 2 Ciracas

5. Semua lansia yang ikut membantu proses penelitian yang dilakukan

6. Teman-teman yang tiada habisnya memberikan suport dan bantuan moril dalam pembuatan artikel ini.

7. Semua pihak yang telah membantu yang tidak bisa disebutkan secara keseluruhan. 


\section{DAFTAR PUSTAKA}

Chasanah Nur. (2017). Hubungan Kualias Tidur Dengan Kualias Hidup Pada Lansia. Jurnal Universitas Muhamadiyah Surakarta.

Darmojo.(2011).Buku Ajar Geriatrik. Balai Penerbit Fakultas Kedokteran Universitas Indonesia.

Davis, Marta. (2017). The Relaxatione Stress Reduction WorkbookBahasaIndonesia ; Achiryani S Hamid dan Budi Anna Keliat. EGC, Jakarta.

Gede, Made Cahyadi. (2011). Insomnia dan Hubungannya terbadap Faktor Psikososial pada Pelayanan Kesehatan Primer. Jurnal. SMF IKJ FK Universitas Udayana/RSUP Sanglah.

Herodes. (2010.) Teknik Relaksasi Progresif terbadap Insomnia pada Lanjut Usia.http://herodessolutiontheoge u.blogspot.com/2010/11/teknikrelaksasi-progresif-terhadap.html

Hidayat. (2011). Penerapan Terapi Relaksasi progresif Pada Kualitas Hidup Lansia. Jurnal UMY

Johnson. (2011). Penerapan Terapi Relaksasi Progresif dengan penurunan frekuensi bangun tidur di tengah malam pada lansia. Penelitian. Jurnal UINIP

Karomah. (2015). Hubungan Tingkat Spiritual lansia dengan tingkat kecemasan menghadapi kematian. Penelitian.UNDIP

Kozier,Barbara,(2014). Fundamental of Nursing,Calofornia $\quad$ :Copyright by.Addist Asley Publishing CompanyLubis Marliyana.(2011). Pemenuhan kebutuhan Istirahat Tidur Pada Lansia. Jurnal. Universitas Sumatra Utara.

Maas, L. Meridean. (2014). Asuban Keperawatan Geriatrik: Diagnosis $N A N D A$,
Kriteria Hasil NOC, \& Intervensi NIC. Jakarta: EGC.

Marks, Dawn B., Marks, Allan D., Smith, C. (2011). Biokimia Kedokteran Dasar: sebuah pendekatan klinis.Jakarta: EGC

Morin, Charles M., Sylvie Rodrigue, Hans Ivers. (2012). Role of Stress, Arousal , and Coping Skill in Primary Insomnia .Psychosomatic Medicine.

Nasrullah, Dede. (2016). Buku Ajar Keperawatan Gerontik Jilid I Dengan Pendekatan Asuhan Keperawatan NANDA, NICNOC. Jakarta Timur : TIM.

Notoadmojo, Soekidjo. (2010). Penelitian Untuk Kesehatan. Rineka Cipta, Jakarta.

Nugroho .(2010). Keperawatan Gerontik. Buku Kedokteran EGC: Jakarta

Nursalam.Siti Pariani. (2017). Konsep dan Penerapan Metodologi Penelitian Ilmu Keperawatan. Salemba Medika, Jakarta.

Potter, Perry. (2011). Fundamental Of Nursing: Consep, Proses and Practice.Edisi 8. Vol. 3. Jakarta : EGC

Rahmadona F. (2012). Penerapan Relaksasi Otot Progresif dengan Pemenuhan Kebutuhan Istirahat Tidur Lansia. Jurnal. Stikes Muhamadiyah Pekajangan Pekalongan.

Setyoadi. 2011. Terapi Modalitas Keperawatan Pada Klien Psikogeriatrik.Salemba Medika. Jakarta

Sugeng,Cecep K. (2011). Gangguan Tidur dalam Psikiatri dan Peran Laboratorium Tidur .Bag. Psikiatri FK UGM/ RSUP dr. SardjitoYogjakarta.

Widad L. (2013). Pengaruh tehnik Relaksasi Progresif Terhadap Pemenuhan Kebutuhan Tidur Lansia. Jurnal. UIN Alaudin Makasar. 